Note

\section{Isolation of Acetylaranotin, Bisdethiodi(methylthio)- acetylaranotin and Terrein as Plant Growth Inhibitors from a Strain of Aspergillus terreus}

\author{
Shinji Kamata, Heiichi SaKaI \\ and Akira Hirota \\ Department of Agricultural Chemistry, \\ University of Osaka Prefecture, \\ Sakai, Osaka 591, Japan
}

Received March 22, 1983

In the course of our research project ${ }^{1)}$ on plant growth regulators among fungal metabolites we noticed that an Aspergillus terreus strain, C-520, which was isolated from a soil sample collected in Takarazuka city, produced several plant growth regulators. One of them is a plant growth promoter and its structure elucidation is in progress. Three of them are plant growth inhibitors. In this paper we wish to report the isolation, identification and biological activities of these three plant growth inhibitors produced by Aspergillus terreus $\mathrm{C}-520$.

Asp. terreus C-520 was cultured in Czapek-Dox medium (40 liters) fortified with yeast extract on a shaking machine for three days at $30^{\circ} \mathrm{C}$. The culture filtrate was extracted with ethyl acetate and the neutral extract was concentrated in vacuo. The concentrate was subjected to silicagel column chromatography (Wako gel C-200). Elution was performed successively with chloroform and chloroformacetone, increasing stepwisely the content of the latter. The eluate with chloroform and that with chloroformacetone $(80: 20)$ showed inhibition of growth of lettuce seedlings (Lactuca sativa L., Great Lakes 366 ). A growth promoter for lettuce seedlings was contained in the eluate with chloroform-acetone $(90: 10)$. The eluate with chloroform was further chromatographed on a silicagel column with a solvent system of $n$-hexane and ethyl acetate $(80: 20)$, and then a Sephadex LH-20 column with methanol. Two biologically active substances designated as C-520A (I) and C-520B (II) were isolated as yellow crystals $(30 \mathrm{mg})$ and a yellow powder $(5 \mathrm{mg})$, respectively. The eluate with chloroform-acetone $(80: 20)$ was rechromatographed on a silicagel column with a solvent system of $n$ hexane-ethyl acetate. Crude crystals of an active substance were obtained from the eluate with $n$-hexane-ethyl acetate $(60: 40)$. Recrystallization from acetone-ethyl acetate gave colorless needles of C-520D (III) $(200 \mathrm{mg})$.
I decomposed above $200^{\circ} \mathrm{C}$ on a hot stage. IR $v_{\max }^{\mathrm{KBr}} 1740$, $1670,1230 \mathrm{~cm}^{-1}$. The molecular formula of $\mathbf{I}$ was determined to be $\mathrm{C}_{24} \mathrm{H}_{26} \mathrm{~N}_{2} \mathrm{O}_{8} \mathrm{~S}_{2}$ from elemental analysis and the high resolution mass spectrum of I. Anal. Found: C 53.86; $\mathrm{H}$ 5.06; N 5.49; $\mathrm{S}$ 11.78. Calcd. for $\mathrm{C}_{24} \mathrm{H}_{26} \mathrm{~N}_{2} \mathrm{O}_{8} \mathrm{~S}_{2}$ : C 53.93; H 4.86; N 5.24; S $11.78 \%$. HR-MS: $\mathrm{M}^{+} \mathrm{m} / z$ 534.1172 (Calcd. for $\mathrm{C}_{24} \mathrm{H}_{26} \mathrm{~N}_{2} \mathrm{O}_{8} \mathrm{~S}_{2}$ 534.1130); $\mathrm{M}^{+}-\mathrm{SCH}_{3} m / z$ 487.1221 (Calcd. for $\mathrm{C}_{23} \mathrm{H}_{23} \mathrm{~N}_{2} \mathrm{O}_{8} \mathrm{~S}$ 487.1175). I was positive to chlorine-o-tolidine-KI and palladium chloride ${ }^{2)}$ and decolorized aqueous potassium permanganate solution. ${ }^{1} \mathrm{H}-\mathrm{NMR}\left(60 \mathrm{MHz}, \mathrm{CDCl}_{3}\right.$, TMS): $\delta 2.05(6 \mathrm{H}, \mathrm{s}), 2.2(6 \mathrm{H}, \mathrm{s}), 3.0(4 \mathrm{H}, \mathrm{m}), 4.6(2 \mathrm{H}, \mathrm{dd})$, $5.75(2 \mathrm{H}, \mathrm{m}), 6.25(2 \mathrm{H}, \mathrm{dd}), 6.5(2 \mathrm{H}, \mathrm{m})$. I was deduced to be a symmetric diketopiperazine. In conclusion, these data mentioned above coincide with those for bisdethiodi (methylthio)-acetylaranotin, ${ }^{3)}$ which is a member of the aranotin group.

II decomposed above $200^{\circ} \mathrm{C}$ on a hot stage. IR $v_{\max }^{\mathrm{KBr}}$ $1730,1690,1220 \mathrm{~cm}^{-1}$. Since II gave the same color reaction as I and the IR spectrum of II was very similar to that of I, II was presumed to belong to the aranotin group. In the mass spectrum of II the molecular ion peak was not observed and the base peak was at $m / z 440$. The composition of the base peak as judged by the high resolution mass spectrum was $\mathrm{C}_{22} \mathrm{H}_{20} \mathrm{~N}_{2} \mathrm{O}_{8}$ (Found $m / z$ 440.1188. Calcd. for $\mathrm{C}_{22} \mathrm{H}_{20} \mathrm{~N}_{2} \mathrm{O}_{8} 440.1218$ ). By comparison of the bahavior on thin layer chromatography ${ }^{4)}$ and the mass spectra of I and II, II was determined to be acetylaranotin. ${ }^{3)}$ Acetylaranotin had already been isolated as a biologically active substance against rhino-, Coxsackie, polio- and parainfluenza viruses, ${ }^{5)}$ while bisdethiodi(methylthio)acetylaranotin had no antiviral activity. ${ }^{5)}$

III melted at $127^{\circ} \mathrm{C}$ and its molecular formula was found to be $\mathrm{C}_{8} \mathrm{H}_{10} \mathrm{O}_{3}$ from elemental analysis and the high resolution mass spectrum. Anal. Found: $\mathrm{C} 62.10 ; \mathrm{H} 6.63 \%$. Calcd. for $\mathrm{C}_{8} \mathrm{H}_{10} \mathrm{O}_{3}$ : C $62.34 ; \mathrm{H} 6.49 \%$. HR-MS: $\mathrm{M}^{+} . \mathrm{m} / z$ 154.0588 (Calcd. for $\mathrm{C}_{8} \mathrm{H}_{10} \mathrm{O}_{3}$ 154.0628). IR $v_{\max }^{\mathrm{KBr}} 3350$, $1675,1620,1210 \mathrm{~cm}^{-1}$. III was positive to 2,4-dinitrophen-
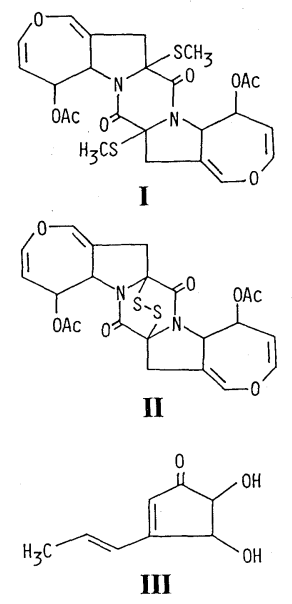

FIG. 1. Structures of I, II and III. 
ylhydrazine and decolorized aqueous potassium permanganate solution. ${ }^{1} \mathrm{H}-\mathrm{NMR}\left(60 \mathrm{MHz},\left(\mathrm{CD}_{3}\right)_{2} \mathrm{CO}, \mathrm{TMS}\right)$ : $\delta 2.0(3 \mathrm{H}, \mathrm{d}, J=6 \mathrm{~Hz}), 3.0(1 \mathrm{H}, \mathrm{s}), 4.1(1 \mathrm{H}, \mathrm{d}), 4.7(1 \mathrm{H}, \mathrm{d})$, $4.9(1 \mathrm{H}$, br. s), $5.9(1 \mathrm{H}, \mathrm{s}), 6.3(1 \mathrm{H}, \mathrm{d}, J=18 \mathrm{~Hz}), 6.8(1 \mathrm{H}$, $\mathrm{dq}, J=18$ and $6 \mathrm{~Hz}$ ). The signals at $\delta 3.0$ and 4.9 disappeared on addition of $\mathrm{D}_{2} \mathrm{O}$. These data coincide with those for terrein. ${ }^{6)}$

The structures of I, II and III are shown in Fig. 1.

The bioassay was conducted at $25^{\circ} \mathrm{C}$ under continuous light ( $c a .2000$ lux) with lettuce seedlings for three days and rice seedlings (Oryza sativa L., cv. Koshihikari) for seven days. I reduced root elongation of lettuce seedlings by about $40 \%$ at a concentration of $100 \mathrm{ppm}$, but II reduced it by about $80 \%$ even at $10 \mathrm{ppm}$. III reduced the root length of lettuce seedlings to $20 \%$ at $50 \mathrm{ppm}$. However, the inhibitory effect of I, II and III on the hypocotyl growth was not clearly observed at these concentrations. I did not affect growth of rice seedlings even at $100 \mathrm{ppm}$, while II reduced the total root length by $50 \%$ at $50 \mathrm{ppm}$ and by $80 \%$ at $100 \mathrm{ppm}$. A dose of $100 \mathrm{ppm}$ of III showed $80 \%$ inhibition of the root elongation of rice seedlings and $40 \%$ inhibition on the total length (length of second leaf sheath plus length of second leaf).

II remarkably inhibits growth of lettuce and rice seedlings. On the other hand, the inhibitory activity of $\mathbf{I}$ is comparatively low. ${ }^{7)}$ The disulfide bridge seems to be necessary for higher biological activity.

Though the yield of III by Asp. terreus C-520 is low, Asp. fischeri Wehmer was reported to produce III in a high yield $(5 \mathrm{mg} / \mathrm{ml}){ }^{8}{ }^{8}$ There is a possibility to get derivatives of III with higher activity by structural modification.

Acknowledgments. We are indebted to the Research
Laboratories of Fujisawa Pharmaceutical Co., Ltd. for taxonomical studies and the sulfur analysis. We are also grateful to Dr. H. Hirota, Department of Chemistry, The University of Tokyo, for measurement of the high resolution mass spectra. We also wish to express our thanks to Dr. T. Yokota, Department of Agricultural Chemistry, The University of Tokyo, for the gift of rice seed.

\section{REFERENCES}

1) A. Hirota, A. Isogai and H. Sakai, Agric. Biol. Chem., 45, 799 (1981).

2) J. Baumler and S. Rippstein, Helv. Chim. Acta, 44, 1162 (1961).

3) R. Nagarajan, L. L. Huckstep, D. H. Lively, D. C. Delong, M. M. Marsh and N. Neuss, J. Am. Chem. Soc., 90, 2980 (1968).

4) R. Rahman, S. Safe and A. Taylor, J. Chromatogr., 53, 592 (1970).

5) P. A. Miller, P. W. Trown, W. Fulmor, G. O. Morton and L. Karliner, Biochem. Biophys. Res. Commun., 33, 219 (1968).

6) R. J. Cole and R. H. Cox, "Handbook of Toxic Fungal Metabolites," Academic Press Inc., New York, N. Y., 1981, p. 769.

7) In general, diketopiperazines have growth inhibitory activity toward plant seedlings, but their activity is not so high: e.g. Yu-Shih Chen, Bull. Agric. Chem. Soc. Jpn., 24, 372 (1960).

8) M. Misawa, T. Nara, K. Nakayama and S. Kinoshita, Nippon Nôgeikagaku Kaishi, 36, 699 (1962). 